\title{
Filogenetik ikan tuna (Thunnus spp.) di Perairan Maluku Utara, Indonesia
}

\author{
[Phylogenetic of tuna fish (Thunnus spp.) in North Mollucas Sea, Indonesia] \\ Nebuchadnezzar Akbar ${ }^{1 凶}$, Muhammad Aris ${ }^{2}$, Muhammad $\operatorname{Irfan}^{2}$, Irmalita Tahir ${ }^{1}$, \\ Abdurrachman Baksir ${ }^{1}$, Surahman ${ }^{3}$, Hawis H Madduppa ${ }^{4}$, Raismin Kotta ${ }^{5}$ \\ ${ }^{1}$ Program Studi Ilmu Kelautan. Universitas Khairun, Ternate \\ ${ }^{2}$ Program Studi Budidaya Perairan. Universitas Khairun, Ternate \\ ${ }^{3}$ Program Pemanfaatan Sumberdaya Perikanan. Universitas Khairun, Ternate \\ ${ }^{4}$ Departemen Ilmu dan Teknologi Kelautan, FPIK-IPB, Bogor \\ ${ }^{5}$ Lembaga Ilmu Pengetahuan Indonesia Ternate
}

Diterima: 6 Juli 2017; Disetujui: 27 Februari 2018

\begin{abstract}
Abstrak
Ikan tuna (Thunnus spp.) adalah ikan pelagis yang memiliki kemampuan ruaya dan nilai komersial. Kondisi oseanografis dan letak geografis mendukung kelimpahan stok sumber daya ikan tuna di Perairan Maluku Utara. Aktifitas penangkapan yang meningkat memberikan pandangan perlu adanya pengkajian filogenetik ikan tuna. Penelitian ini bertujuan untuk memperoleh informasi filogenetik ikan tuna di perairan Maluku Utara. Metode yang digunakan adalah metode PCR-Sekuensing pada lokus mtDNA control region. Analisis molekuler meliputi ekstraksi, Polymerase Chain Reaction (PCR), elektroforesis dan sekuensing DNA. Rekonstruksi pohon filogenetik dengan metode Neighbor joining dengan model evolusi Kimura 2-parameter dilakukan menggunakan aplikasi MEGA5. Hasil penelitian menemukan empat clade spesies ikan tuna yang berbeda (tuna mata besar, sirip kuning, alalunga, dan cakalang). Jarak genetik tuna mata besar (Thunnus obesus) dengan sirip kuning (Thunnus albacares) adalah 0,084; tuna mata besar dengan tuna alalunga (Thunnus albacore) adalah 0,163; tuna sirip kuning dengan tuna alalunga sebesar 0,174; tuna mata besar dengan cakalang (Katsuwonus pelamis) adalah 0,294; cakalang dengan tuna alalunga adalah 0,312; dan tuna sirip kuning dengan cakalang adalah 0,297 . Semua hasil menunjukkan perbedaan genetik signifikan. Namun dapat dijelaskan bahwa spesies tuna berasal dari satu keturunan. Filogeografi tuna tidak memiliki batas distribusi yang nyata spesies.
\end{abstract}

Kata penting: filogeografi, jarak genetik, pohon filogenetik, Thunnus

\begin{abstract}
The tuna fish (Thunnus spp.) is highly migratory and commercial tuna fishery. The fish tuna abudance supported oceanography and geography condition in North Mallucas Sea. The fishery targets catch increase on fish tuna provided a view of the need for assessment of phylogenetic tuna. The study was conducted to infer the phylogenetic in North Mollucas Sea. The research method was PCR-Sequensing. Moleculer analysis included extraction, Polymerase Chain Reaction (PCR), electrophoresis and DNA sequencing in control region mtDNA locus. Phylogenetic reconstructed with Neigbor joining with Kimura 2-parameter model using MEGA5. The result showed that four clade (bigeye, yellowfin, alalunga and skipjack). Genetic distance between bigeye with yellowfin was (0.084), bigeye with alalunga (0.163), yellowfin with alalunga $(0.174)$, bigeye with skipjack $(0.294)$, skipjack with alalunga $(0.312)$ and yellowfin with skipjack (0.297). The overall result showed significant genetic different. That information explain about one populations species tuna. The tuna phylogeography unlimitedin geographic distributions.
\end{abstract}

Keywords: genetic distance, phylogenetic, phylogeography, Thunnus

\section{Pendahuluan}

Wilayah perairan kepulauan Maluku Utara telah lama dikenal sebagai daerah ruaya dan penangkapan ikan paling produktif di Indonesia (KKP 2011). Total produksi penangkapan ikan tuna pada tahun 2011 sebesar 106,5 ton th $^{-1}$ (KKP 2011). Bailey et al. (2012) mengatakan bahwa terdapat beberapa jenis tuna di perairan Indonesia

\footnotetext{
$\triangle$ Penulis korespondensi

Alamat surel: nezzarnebuchad@yahoo.co.id
}

antara lain tuna sirip kuning (Thunnus albacares), tuna mata besar (Thunnus obesus) dan ikan cakalang (Katsuwonus pelamis). Selain itu wilayah ini secara geografis terletak di bagian timur Indonesia yang dibatasi oleh Samudra Pasifik, Laut Maluku, Laut Halmahera, dan Laut Seram. Kedudukan ini menyebabkan perairan kedua wilayah dipengaruhi oleh massa arus lintas Indonesia (Arlindo). Molcard et al. (2001) menjelaskan Arlindo merupakan aliran arus antarsamudra yang melewati Indonesia 
dan memiliki peranan yang penting dalam sistem sirkulasi massa air yaitu menyuplai massa air ke Samudra Hindia. Selain itu, Gordon (2005) melaporkan perairan Maluku Utara dilewati arus termoklin Pasifik selatan dan termoklin Pasifik utara. Pembentukan arus ini akan membantu ikan khususnya tuna dalam beruaya dan bertemu antarpopulasi.

Ikan tuna merupakan spesies pelagis yang beruaya jauh, menyebar secara luas dan beruaya mengikuti pola arus perairan (Bremer et al. 1998, Chen et al. 2005). Hal ini memberikan peluang ikan bertemu dengan populasi ikan yang lain di perairan. Gaylord \& Gaines (2000) mengatakan bahwa arus laut dapat memengaruhi persebaran populasi dan struktur genetik ikan. Gordon \& Fine (1996) juga melaporkan bahwa rute pertukaran gen antara organisme tropis di Samudra Hindia dengan Samudra Pasifik terus berlangsung hingga saat ini dan pertukaran gen secara garis besar melalui perantara Arlindo.

Dilihat dari sejarah geologi, Maluku Utara merupakan kepulauan yang terbentuk akibat peristiwa tubrukan lempeng yang terjadi sehingga menyebabkan kenaikan kerak bumi ke atas permukaan laut. Hal ini menyebabkan isolasi yang panjang dan rumitnya pembentukan pulau ini secara geologi telah memberikan fenomena menarik tehadap jenis fauna yang menghuni pulau Halmahera (Hall 1998). De Jong (1998) mengatakan bahwa secara geologis antara pulau Halmahera dan Seram sangat berbeda, di mana pulau Halmahera secara geografis mengarah ke bagian timur Indonesia sedangkan pulau Seram menjulur ke bagian barat Indonesia. Variasi kondisi lingkungan diduga dapat menimbulkan variabilitas genetik pada ikan laut dan perubahan struktur genetik yang diakibatkan terjadinya perubahan tinggi muka air laut pada jaman Pleistosen (Saunders et al. 1986, Borsa 2003).
Berbagai penjelasan mengenai geologi dan oseanografi pada Maluku Utara memberikan pandangan bahwa perlu adanya suatu kajian filogenetik untuk menjawab hubungan kekerabatan yang terjadi antara ikan, khususnya tuna yang memiliki kemampuan ruaya yang tinggi. Pengetahuan tentang hubungan kekerabatan suatu spesies diperlukan untuk mempelajari evolusi beberapa taksa yang memiliki kekerabatan dengan membandingkan sekuen DNA nya (Ubadillah \& Sutrisno 2009). Baldauf (2003) mengatakan ilmu filogenetik dapat memperkirakan evolusi yang terjadi pada masa lalu dengan membandingkan sekuen DNA atau protein. Campbell et al. (2012) menyebutkan filogenetik dapat menunjukkan hubungan evolusioner suatu organisme yang disimpulkan dari data morfologis dan molekuler.

Penelitian filogenetik ikan tuna telah dilakukan oleh beberapa peneliti (Chow \& Kishino 1995, Finnerty \& Block 1995, Elliott \& Ward 1995, Bremer et al. 1997, Chow et al. 2003) yang melihat hubungan filogenetik diantara spesies tuna dengan menggunakan genom mitokondria dan nuclear. Hasil penelitian menunjukkan bahwa terdapat hubungan yang kuat diantara spesies tuna dan terjadi pengelompokan yang berbeda antarspesies. Penelitian ikan tuna sendiri di Indonesia dilakukan oleh Permana et al. (2007) yang mengkaji variasi genetik ikan tuna sirip kuning (Thunnus albacares) dan Suman et al. (2013) yang melihat struktur genetik ikan tuna pada spesies tuna mata besar (Thunnus obesus); sedangkan kajian filogenetik ikan tuna di Indonesia sendiri, hingga sekarang belum terpublikasi dan ditemukan.

Analisis hubungan filogenetik ikan tuna menggunakan teknik DNA sequencing. Teknik ini dipakai untuk mendapatkan informasi genetik dan metode untuk memperoleh urutan basa nukleotida pada molekul DNA (Sanger et al. 1977). Freeland (2005) mengatakan DNA sekuensing merupakan 

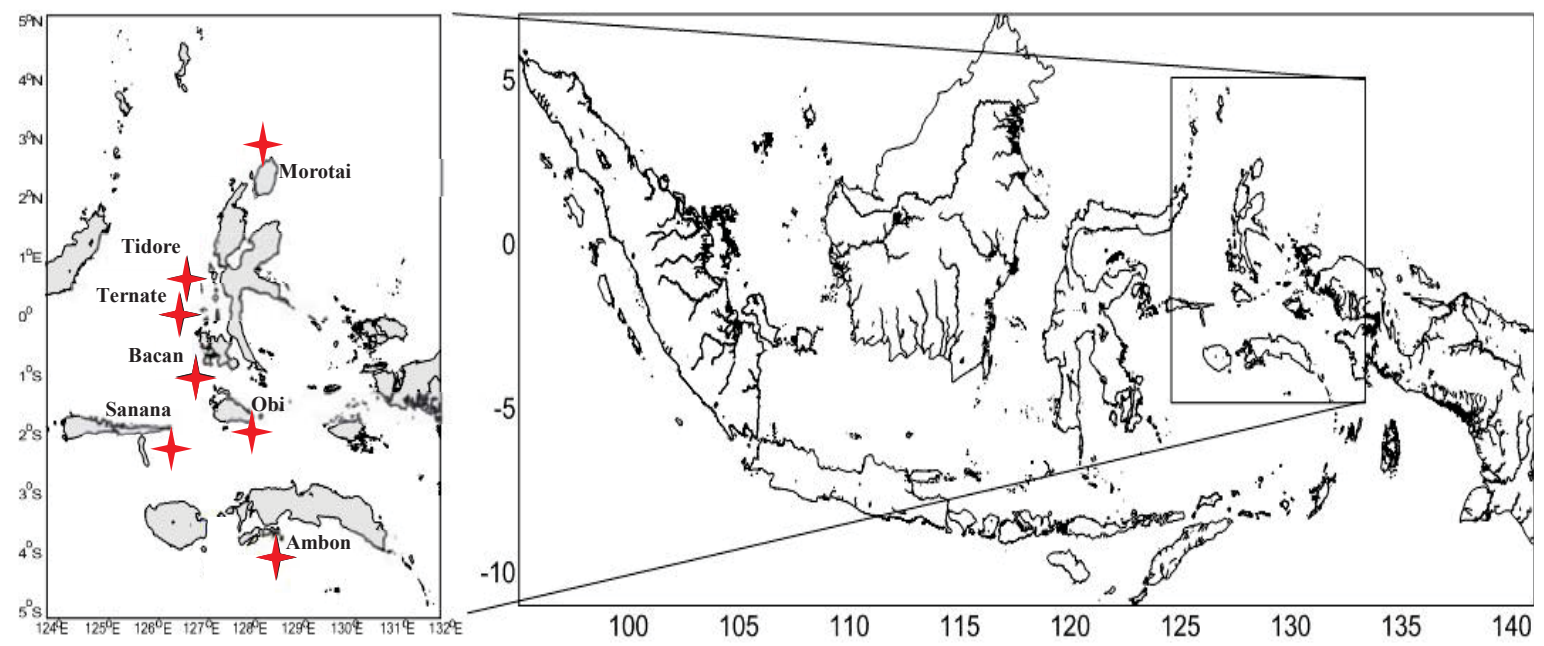

Gambar 1. Zona operasi penangkapan ikan tuna di Perairan Maluku Utara, Indonesia

satu-satunya metode untuk mengidentifikasi pasangan basa dengan tepat antara individu yang berbeda dan memungkinkan untuk menyimpulkan hubungan evolusi. Selain itu teknik ini sangat mudah, cepat, efisien sehingga banyak digunakan sebagai aplikasi dasar (Graham \& Hill 2001, Ubadillah \& Sutrisno 2009).

\section{Bahan dan metode}

Koleksi sampel

Koleksi sampel dilakukan pada Juli-September tahun 2016 pada Pangkalan Pendaratan Ikan (PPI) dan Pelabuhan Perikanan Nusantara (PPN) di pulau Bacan, Tidore, Ternate, Obi, Sanana,Morotai dan Ambon (Gambar 1). Total sampel yang ditemukan pada Maluku Utara $(\mathrm{n}=81)$ individu. Sampel difoto, diukur panjang, dan diambil bagian sirip dada sepanjang $3 \mathrm{~cm}$; setelah itu disimpan dalam tabung yang telah terisi larutan etanol 96\% untuk pengawetan.

\section{Ekstraksi DNA, Polymerase Chain Reaction}

(PCR), elektroforesis, dan sekuensing

Isolasi sampel DNA mitokondria dilakukan dengan larutan Chelex 10\% (Walsh et al. 1991).
Ekstraksi DNA dimulai dengan pengambilan sampel jaringan. Amplifikasi dilakukan pada lokus mitocondrial DNA control region menggunakan primer forward CRK 5'-AGCTC AGCGC CAGAG CGCCG GTCTT GTAAA-3' dan primer reverse CRE 5'-CCTGA AGTAG GAACC AGATG-3'(Lee et al. 1995). Profil PCR meliputi denaturasi awal pada suhu $94^{\circ} \mathrm{C}$ selama 15 detik, 38 siklus yang meliputi denaturasi pada $94^{\circ} \mathrm{C}$ selama 30 detik, annealing pada $50^{\circ} \mathrm{C}$ selama 30 detik, dan extension pada $72^{\circ} \mathrm{C}$ selama 45 detik, selama $72^{\circ} \mathrm{C}$ untuk 5 menit.

Proses elektroforesis dilakukan dengan memasukkan 1 gram agarosa erlenmeyer ditambahkan 100 mL TAE 1x dan dipanaskan di dalam mikrowave kemudian ditambahkan $4 \mathrm{uL}$ EtBr. Gel agarosa yang sudah jadi kemudian dituangkan di cetakan yang sudah dipasang sisir pembuat sumur dan didiamkan selama 30 menit. Hasil amplifikasi DNA dilakukan dengan metode Sanger (Sanger et al. 1977).

\section{Analisis data}

Data sequen yang diperoleh dilakukan pengeditan, lalu di BLAST untuk memastikan 
akurasi sampel. Hubungan kekerabatan antarpopulasi ditentukan berdasarkan parameter jarak genetik (Nei 1972). Selanjutnya analisis statistik terhadap perbedaan jarak genetik (Nei 1987), identifikasi spesies, dan rekonstruksi pohon filogenetik pada sampel. Keseluruhan menggunakan metode Neighbor joining dan model evolusi Kimura 2-parameter model yang dilakukan dengan aplikasi MEGA5 (Tamura et al. 2011).

\section{Hasil}

\section{Karakteristik molekuler}

Panjang fragmen hasil amplifikasi PCR dengan primer CRK-CRE pada lokasi mtDNA control region adalah 517 bp dari total 81 sampel ikan tuna ( Tabel 1). Hampir semua substitusi nukleotida yang diamati ditemukan antara individu (Tabel 3). Jumlah subtitusi nukleotida antar ikan cakalang (K. pelamis) adalah 28 dan lebih besar dibandingkan dengan subtitusi nukeotida spesies tuna lainnya (Tabel 2).

Pada ikan tuna (Thunnus), spesies yang mendominasi subtitusi adalah tuna mata besar (Thunnus obesus) dengan jumlah subtitusi sebesar 13 nukleotida, tuna alalunga (Thunnus albacore) dengan jumlah pergantian nukleotida adalah 11, dan tuna sirip kuning (Thunnus albacares) memiliki 10 subtitusi nukeotida (Tabel 2). Perbedaan jumlah subtitusi tuna mata besar dengan tuna alalunga adalah 23 nukleotida, subtitusi nukleotida tuna mata besar dengan tuna sirip kuning adalah 19 nukleotida $(0,8 \%)$, antara ikan tuna mata besar dengan ikan cakalang sebesar 33 nukleotida, ikan cakalang dengan tuna sirip kuning sebanyak 38 nukeotida, tuna alalunga dengan ikan cakalang sebanyak 30 nukeotida; sedangkan ikan tuna alalunga dengan sirip kuning 28 nukelotida (Tabel 4).

Tabel 1. Spesies, nama umum, lokasi, tahun, singkatan dan jumlah sampel ikan tuna (Thunnus spp.) yang ditemukan

\begin{tabular}{lllcc}
\hline Spesies & Nama umum & Lokasi dan tahun & Singkatan & Jumlah sampel \\
\hline Thunnus obesus & Bigeye & Maluku Utara, 2016 & BET & 40 \\
Thunnus albacares & Yellowfin & Maluku Utara, 2016 & YFT & 33 \\
Thunnus alalunga & Albacore & 6Maluku utara, 2016 & ALB & 7 \\
Katsuwonus pelamis & Skipjack & Maluku utara, 2016 & SKJ & 1 \\
\hline & & Total & & 81 \\
\hline
\end{tabular}

Tabel 2. Tipe nukleotida, spesies dan subtitusi nukleotida pada ikan tuna (Thunnus spp.)

\begin{tabular}{|c|c|c|c|c|c|}
\hline \multirow{2}{*}{ Tipe nukleotida } & \multirow{2}{*}{ Spesies } & \multicolumn{4}{|c|}{ Subtitusi } \\
\hline & & Cakalang & Mata besar & Sirip kuning & Alalunga \\
\hline \multirow{4}{*}{80} & Cakalang & 28 & - & - & - \\
\hline & Mata besar & - & 13 & - & - \\
\hline & Sirip kuning & - & - & 10 & - \\
\hline & Alalunga & - & - & - & 11 \\
\hline
\end{tabular}


Tabel 3. Distribusi haplotipe dan urutan subtitusi nukleotida ikan tuna

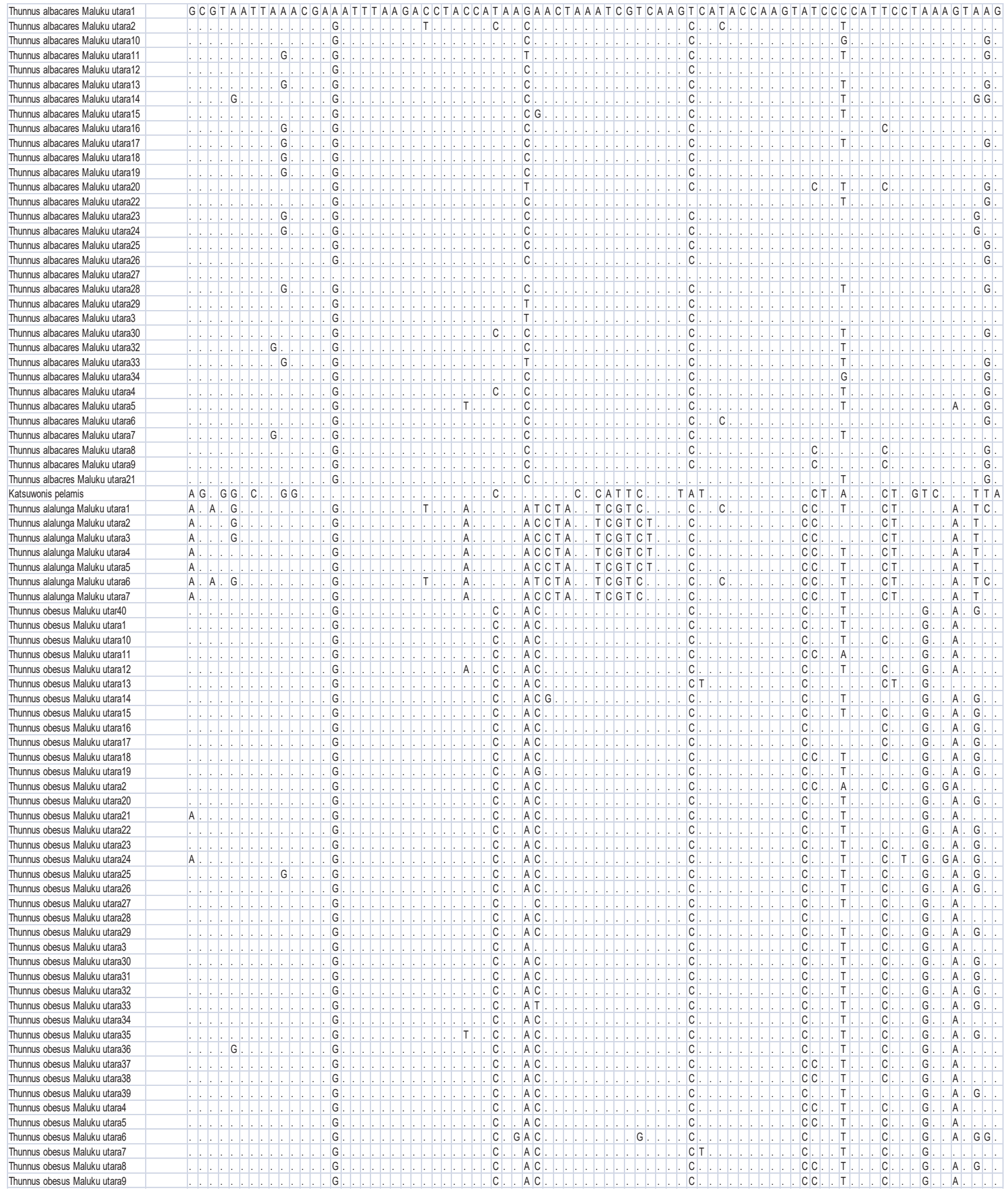

Tabel 4. Subtitusi nukleotida antarspesies ikan tuna (Thunnus spp.)

\begin{tabular}{clcccc}
\hline \multirow{2}{*}{ Tipe nukleotida } & \multirow{2}{*}{ Spesies } & \multicolumn{4}{c}{ Subtitusi } \\
\cline { 3 - 6 } & & Cakalang & Mata besar & Sirip kuning & Alalunga \\
\hline \multirow{3}{*}{80} & Cakalang & - & 33 & 38 & 30 \\
& Mata besar & - & - & 19 & 23 \\
& Sirip kuning & - & - & - & 28 \\
& Alalunga & - & - & - & - \\
\hline
\end{tabular}


Analisis filogenetik mtDNA

Analisis filogenetik menggunakan metode Neighbor-joining dengan model Kimura 2-parameter model diperoleh empat clade yakni clade pertama untuk spesies ikan tuna mata besar (Thunnus obesus), Clade kedua untuk tuna sirip kuning (Thunnus albacares), Clade ketiga adalah ikan tuna albacore (Thunnus alalunga) dan clade keempat adalah ikan cakalang (Katsuwonus pelamis) (Gambar 2). Pohon filogenetik yang dibangun memiliki nilai bootstrap diantara 57-100\% pada setiap cabang pada kelompok populasi.
Hubungan kekerabatan diperlihatkan oleh kelompok populasi tuna mata besar dan tuna sirip kuning, sedangkan kelompok tuna alalunga dan cakalang terpisah jauh. Hal ini menjelaskan bahwa terjadi divergensi secara genetik antara kelompok tuna alalunga dan cakalang. Rekonstruksi pohon filogenetik didukung hasil analisis jarak genetik antarempat spesies. Jarak genetik tuna mata besar dengan tuna sirip kuning berkerabat dekat, kemudian berkerabat jauh dengan tuna alalunga dan cakalang (Tabel 5).

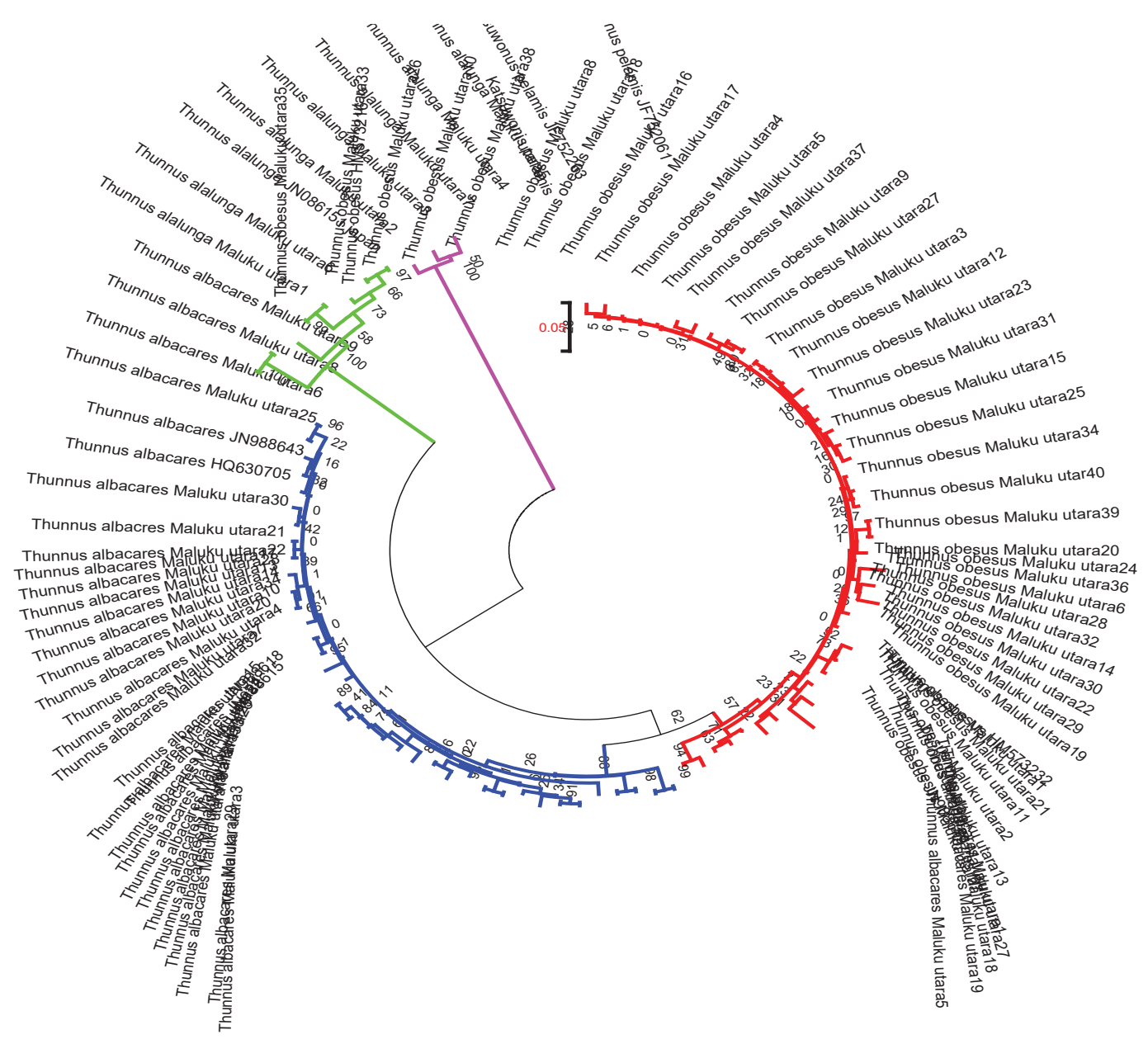

Gambar 2. Pohon filogenetik spesies tuna (Thunnus spp.) Maluku Utara, (tuna mata besar = garis merah, tuna sirip kuning = garis biru, tuna alalunga $=$ garis hijau, ikan cakalang $=$ garis merah muda. 
Tabel 5. Jarak genetik antarspesies ikan tuna (Thunnus spp.) di Perairan Maluku Utara

\begin{tabular}{ccc}
\hline Spesies 1 & Spesies 2 & Jarak Genetik \\
\hline Tuna sirip kuning & Cakalang & 0,297 \\
Tuna sirip kuning & Tuna alalunga & 0,174 \\
Cakalang & Tuna alalunga & 0,312 \\
Tuna sirip kuning & Tuna mata besar & 0,084 \\
Cakalang & Tuna mata besar & 0,294 \\
Tuna alalunga & Tuna mata besar & 0,163 \\
\hline
\end{tabular}

\section{Pembahasan}

Total jumlah haplotipe sebanyak 80 panjang basa (bp) dan subtitusi nukleotida antara spesies tuna (Thunnus Spp) dengan cakalang berbeda. Hasil yang sama juga diperoleh oleh Chow \& Kishino (1995) yakni 51 haplotipe dengan total 292 panjang basa (bp) dan jumlah subtitusi berkisar 35-42. Perbedaan ini dikarena jumlah sampel yang berbeda. Penelitian Chow \& Kishino (1995) menggunakan tiga individu pada spesies tuna yang terbagi atas satu individu sampel yang dikoleksi dan dua sampel dari data DDJB (DNA Data Bank of Japan), sedangkan sampel koleksi yang digunakan dalam penelitian ini berjumlah 81 spesies dan terbagi atas sampel ikan tuna mata besar (T. obesus), sirip kuning (T. albacares), alalunga (T. albacore), dan cakalang (K. pelamis) (Tabel $4)$.

Clade pertama adalah populasi ikan tuna mata besar yang memperlihatkan pencampuran antara individu dengan yang lain. Hal ini memungkinkan terjadi dan menjelaskan bahwa genetik kedua populasi ini sangat dekat dan memiliki kesamaan. Hasil penelitian yang sama juga diperoleh Grewe \& Hampton (1998) di perairan Samudra Pasifik, Martinez \& Zardoya (2005) dan Martinez et al. (2006) pada perairan Samudra Atlantik, Chiang et al. (2006) pada Laut Cina, Filipina dan Samudra Pasifik bagian barat, dan Chiang et al. (2008) di perairan Samudra Hindia.
Clade kedua adalah ikan tuna sirip kuning juga menunjukkan kemiripan pengelompokan berdasarkan individu yang sama. Hal ini mengindikasikan bahwa populasi ikan ini adalah satu keturunan dan beruaya dengan pola ruaya pada lokasi yang sama sehingga mengakibatkan kedua populasi ini menjadi mirip secara genetic. Hasil yang diperoleh didukung oleh Kunal \& Kumar (2013) yang menemukan bahwa ditemukan seluruh haplotipe terbentuk didalam pohon filogenetik dan tidak menunjukkan adanya perbedaan secara genetik di perairan India.

Clade ketiga adalah terdapat tuna alalunga juga menunjukkan pembentukan kelompok. Hal ini menunjukkan bahwa hasil yang diperoleh memiliki kemiripan secara geneologi di dalam individu. Hal yang sama juga diperoleh Nakadate et al. (2005) yang memperlihatkan adanya pencampuran populasi dari dua lokasi yang berbeda yakni Atlantik dan Laut Mediterania. Perlu diketahui bahwa ikan tuna alalunga merupakan spesies yang jarang ditemukan di perairan Indonesia, namun tidak menutup kemungkinan tersebar masuk ke perairan Indonesia dan memiliki kedekatan genetik antarindividu yang ditemukan pada daerah lain. Sebagaimana yang ditemukan Davies et al. (2011) bahwa tingkat kemiripan genetik rendah antara ikan tuna alalunga (T. albacore) yang ter-dapat di bagian Atlantik Utara dan Laut Mediterania.

Clade empat ditemukan ikan cakalang yang digunakan sebagai outgroup. Hasil rekon- 
struksi pohon menunjukkan ikan cakalang terdapat di luar kelompok yang lainnya dan berkerabat jauh dengan kelompok spesies tuna (Thunnus spp.). Hal ini diungkapkan Collette \& Chao (1975) in Matsumoto et al. (1984) bahwa spesies ikan cakalang merupakan kerabat jauh dengan spesies tuna namun akan berkerabat dekat jika dibandingkan dengan spesies tuna lainya seperti Auxis dan Euthynnus. Keseluruhan hasil sama seperti yang dilaporkan Chow dan Kishino (1995) yang menemukan tiga clade yang berbeda namun setiap clade terdapat individu yang sama. Chow et al. (2003) menjelaskan bahwa tuna mata besar secara genetik lebih dekat dan berkerabat dengan tuna sirip kuning dibandingkan dengan tuna albacore. Hal serupa juga dilaporkan Vinas \& Tudela (2009) bahwa terdapat sepuluh clade yang berbeda diantara spesies tuna yakni tuna sirip biru Atlantik (T. atlanticus), sirip kuning (T. albacares), tongkol abu-abu (T. tonggol), tuna mata besar (T. obesus), tuna sirip biru selatan (T. moccoyii), tuna sirip biru pasifik ( $T$. orientalis), tuna sirip biru (T. thynnus), dan tuna alalunga (T. albacore). Hal yang sama juga dilaporkan Tseng et al. (2012) dan Kunal \& Kumar (2013) bahwa terdapat empat clade spesies ikan tuna yang berbeda.

Hasil identifikasi yang menemukan spesies ikan tuna alalunga (T. albacore) di perairan Maluku Utara kemungkinan disebabkan oleh dua faktor. Pertama, larva ikan tuna albacore beruaya masuk mengikuti anakan ikan tuna lainnya, sebagaimana Chow et al. (2003) menjelasakan bahwa larva dan juvenile besar spesies ikan tuna albacore (T. alalunga), tuna mata besar (T. obesus), cakalang (skipjack), dan tuna sirip kuning (T. albacares) tersebar luas di semua perairan sementara spesies tuna sirip biru pasifik utara (Thunnus orientalis) dan spesies Thunnini lainnya yang cenderung lebih dekat dengan pulau-pulau atau daerah pesisir.
Faktor kedua adalah kondisi oseanografis yang mendorong larva tuna albacore terbawa masuk ke perairan Maluku Utara, karena oseanografi merupakan salah satu faktor yang membantu dalam proses pertukaran gen antarpopulasi ikan yang memiliki perbedaan jarak geografis yang jauh. Arus yang terbentuk akibat tiupan angin secara global membantu dalam membawa organisme kecil yang belum memiliki kemampuan berenang. Laevastu \& Hayes (1981) mengatakan arus dapat memberikan pengaruh yang besar pada keberadaan ikan karena dapat memengaruhi rute ruaya ikan, tingkah laku ikan, distribusi makan, penyebaran dan kelimpahan ikan serta dapat membawa telur dan larva ikan dari tempat pemijahan ke tempat asuhan. Yuen (1955) in Mimura (1963) menjelaskan telur ikan tuna mata besar ditemukan di perairan Samudra Pasifik dan tercampur dengan telur ikan tuna lainya.

Jarak genetik yang ditemukan diantara spesies tuna (Tabel 5) memperlihatkan kedekatan genetik tuna mata besar ( $T$. obesus) dengan tuna sirip kuning (T. albacares). Hasil yang sama diperoleh Chiang et al. (2008), Wijana \& Mahardi ka (2010) dan Tseng et al. (2012). Kedekatan genetik ikan cakalang (K.pelamis) yang diperoleh juga dilaporkan Tseng et al. (2012). Perbedaan jarak genetik ini diduga karena pola penyebaran empat spesies ini berbeda sehingga memberikan peluang pertemuan yang kecil dan menimbulkan tidak adanya aliran gen antar populasi. Collette \& Nauen (1983) dan Chow et al. (2003) melaporkan tuna mata besar (T.obesus) dan tuna sirip kuning (T. albacares) terdistribusi luas di semua perairan tropis dan memiliki bentuk morfologi yang berbeda saat larva.

\section{Simpulan}

Hasil analisis filogenetik ikan tuna (Thunnus spp.) menunjukkan bahwa terdapat empat clade yang berbeda namun tidak terdapat perbe- 
daan genetik yang signifikan diantara spesies tuna. Secara umum dapat dijelaskan bahwa spesies tuna berasal dari satu keturunan dan secara filogeografi tidak memiliki batas distribusi yang nyata.

\section{Daftar pustaka}

Baldauf SL. 2003. Phylogeny for the faint of heart: A tutorial. Genetics, 19(6): 345351.

Bailey M, Flores J, Pokajam S, Sumaila UR. 2012. Towards better management of Coral Triangle tuna. Ocean \& Coastal Management Journal, 63(1): 30-42.

Borsa P. 2003. Genetic structure of round scad mackerel Decapterus macrosoma (Carangidae) in the Indo-Malay archipelago. Marine Biology, 142(2): 575-581.

Bremer AJR, Naser I, Ely B.1997. Orthodox and unorthodox phylogenetic relationships among tunas revealed by the nucleotide sequence analysis of the mitochondrial control region. Journal of Fish Biology, 50(3): 540-554

Bremer JRA, Stequert B, Robertson NW, Ely B. 1998. Genetic evidence for inter-oceanic subdivision of bigeye tuna (Thunnus obesus) populations. Marine Biology,132(4): 547-557.

Campbell NA, Reece BJ, Urry LA, Cain ML, Wasserman SA, Minorsky PV, Jackson RB. 2012. Biologi Jilid 1, Edisi 8. Penerbit Erlangga. Jakarta. $568 \mathrm{hlm}$.

Chen IC, Lee PF, Tzeng WN. 2005. Distribution of albacore (Thunnus alalunga) in the Indian Ocean and its relation to environmental factors. Fisheries Oceanography, 14(1): 71-80.

Chiang HC, Hsu CC, Lin HD, Ma GC, Chiang TY, Yang HY. 2006. Population structure of bigeye tuna (Thunnus obesus) in the South China Sea, Philippine Sea and western Pacific Ocean inferred from mitochondrial DNA. Fisheries Research, 79(2): 219-225.

Chiang HC, Hsu CC, Wu GCC, Chang SK, Yang HY. 2008. Population structure of bigeye tuna (Thunnus obesus) in the Indian Ocean inferred from mitochondrial DNA. Fisheries Research, 90(1): 305-312.
Chow S, Kishino H. 1995. Phylogenetic relationships between tuna species of the genus Thunnus (Scombridae: Teleostei): inconsistent implications from morphology, nuclear and mitochondrial genomes. Journal of Moleculer Evolution, 41(2): 741-748

Chow S, Nohara T, Tanabe T, Itoh S, Tsuji Y, Nishikawa S, Uyeyanagi K, Uchikawa. 2003. Genetic and morphological identification of larval and small juvenile tunas (Pisces: Scombridae) caught by a midwater trawl in the western Pacific. Bullettin of Fisheries Research Agency, 8(3): 1-14

Collette BB, Nauen CE. 1983. FAO species catalogue. Vol. 2. Scombrids of the world. An annotated and illustrated catalogue of tunas, mackerels, bonitos and related species known to date. FAO Fisheries Synopsis, 125 Volume 2: $137 \mathrm{p}$.

Davies CA, Gosling EM, Was A, Brophy D, Tysklind N. 2011. Microsatellite analysis of albacore tuna (Thunnus alalunga): population genetic structure in the NorthEast Atlantic Ocean and Mediterranean Sea. Marine Biology, 158(2): 2727-2740.

de Jong R. 1998. Halmahera and Seram: different histories, but similar butterfly faunas. Biogeography and Geological Evolution of SE Asia. Backbuys Publisher. Leiden, Netherlands. pp 315-325

Elliott NG, Ward RD. 1995. Genetic relationships of eight species of Pacific tuna (Teleostei, Scombridae) inferred from allozyme analysis. Marine and Freshwater Research. 46(1): 1021-1032.

Finnerty JR, Block AB. 1995. Evolution of cytochrome $\mathrm{b}$ in the Scombroidei (Teleostei: molecular insights into billfish (Istiophoridae and Xiphiidae relationships). Fishery Bulletin, 93(1): 78-96.

Freeland JR. 2005. Molecular Ecology. British library cataloguing in publication data. Minion-regular by Thomson Press (India) limited. New Delhi, India.

Gaylord B, Gaines SD. 2000. Temperature or transport? Range limits in marine species mediated solely by flow. American Naturalist, 155(6): 769-789.

Gordon AL, Fine RA. 1996. Pathways of water between the Pacific and Indian oceans in 
the Indonesian seas. Nature, 379(2): 146149.

Gordon AL. 2005. The Indonesian seas oceanography of and their throughflow. Oceanography, 18(4): 14-27.

Graham CA, Hill AJM. 2001. DNA Sequencing Protocols, second edition. Humana Press. Totowa, New Jersey.

Grewe P, Hampton J. 1998. An assessment of bigeye (Thunnus obesus) population structure in the Pasific Ocean, based on mitochondrial DNA and DNA microsatellite analysis. Marine Research. Commonwealth Scientific and Industrial Research Organitation, Australia.

Hall R. 1998. The plate tectonics of Cenozoic SE Asia and the distribution of land and sea. In: Hall R, Holloway JD (Eds.). Biogeography and Geological Evolution of SE Asia. Backhuys Publisher, Leiden. pp. 99-132

KKP (Kementerian Kelautan dan Perikanan). 2011. Kelautan dan Perikanan dalam Angka 2011. Pusat Data Statistik dan Informasi, Jakarta.

Kunal SP, Kumar G. 2013. Cytochrome oxidase I (COI) sequence conservation and variation patterns in the yellowfin and longtail tunas. International Journal of Bioinformatics Research andApplications, 9(3): 301-309.

Laevastu T, Hayes ML. 1981. Fisheries Oceanography and Ecology. Fishing News Book Ltd. New York. 238 p.

Lee WJ, Conroy J, Howell WH, Kocher TD. 1995. Structure and evolution of teleost mitochondrial control regions. Moleculer Evolution, 41(1): 54-66.

Martinez P, Zardoya R. 2005. Genetic struktur of bigeye tuna (Thunnus obesus) in the Atlantic Ocean. Collective Volume of Scientific Papers, 57(1): 195-205.

Martinez P, Gonzales GE, Castilho R, Zardoya R. 2006. Genetic diversity and historical demography of Atlantic bigeye tuna (Thunnus obesus). Molecular Phylogenetics and Evolution, 39(3): 404-416.

Matsumoto WM, Skiliman RA, Dizon AE. 1984. Synopsis of biological data on skipjack tuna (Katsuwonus pelamis). FAO Fisheries Synopsis, 136: 1-92.
Mimura K. 1963. Synopsis on the Biology of Bigeye Tuna Parathunnus mebachi Kishinouye 1923 (Indian Ocean). Species Synopsis No, 11. FAO Fisheries Biology Synopsis No, 54: 350-379

Molcard R, Feux M, Syamsudin F. 2001. The Indonesian throughflow within Ombai Strait. Deep Sea Research I, 48 (5): 1237-1253.

Nakadate M, Vinas J, Corriero A, Clarke S, Suzuki N, Chow S. 2005. Genetic isolation between Atlantic and Mediterranean albacore populations inferred from mitochondrial and nuclear DNA markers. Journal of Fish Biology, 66(4): 15451557.

Nei M. 1972. Genetic distance between population. American Nature, 106: 283-292.

Nei M. 1987. Moleculer Evolutionary Genetics. Columbia University. Press. New York. $512 \mathrm{p}$

Permana GN, Hutapea JH, Haryanti, Sembiring SBM. 2007. Variasi genetik ikan tuna sirip kuning (Thunnus albacares) dengan analisis elektroforesis allozyme dan mtDNA. Jurnal Riset Akuakultur, 2(1): 41-50.

Sanger F, Nicklen S, Coulson AR. 1977. DNA sequencing with chain-terminating inhibitors. Proceeding of the National Academy of Sciences of the United States of America, 74(12): 5463-5467.

Saunders NC, Kessler LG, Avise JC. 1986. Genetic variation and geographic differentiation in mitochondrial DNA of the horseshoe crab (Limulus polyphemus). Genetics, 112 (2): 613-627.

Suman A, Irianto HE, Amri K, Nugraha B. 2013. Population structure and reproduction of bigeye tuna (Thunnus obesus) in Indian Ocean at western part of Sumatera and southern part of Java and Nusa Tenggara. Indian Ocean Tuna Commission, 8 Oktober 2013. 1-14 hal.

Tamura K, Peterson D, Peterson N, Stecher G, Nei M, Kumar S. 2011. MEGA5: Molecular evolutionary genetics analysis using maximum likehood, evolutionary distance and maximum parsimony method. Moleculer Biology Evolution, 28(10): 2731-2739. 
Tseng MC, Jean TC, Smith PT, Hung YH. 2012. Interspecific and intraspecific genetic diversity of Thunnus species. In: Çalişkan M (Editor). Analysis of Genetic Variation in Animals. InTech, Rijeka - Croatia. pp 63-82

Ubadillah R, Sutrisno H. 2009. Pengantar biosistematik: teori dan praktek. LIPI Press. Jakarta. 325 hlm

Vinas J, Tudela S. 2009. A validated methodology for genetic identification of tuna species (Genus Thunnus). PLoS ONE, 4(10): 110 .
Walsh PS, Metzger DA, Higuchi R. 1991. Chelex100 as a medium for Simple extraction of DNA for PCR based typing from forensic material. Biotechniques, 10(4): 506513.

Wijana IMS, Mahardika IGN. 2010. Struktur genetika dan filogeni yellowfin tuna (Thunnus albacores) berdasarkan sekuen DNA mitokondria control region sitokrom oksidase I pada diversitas zone biogeografi. Jurnal Bumi Lestari, 10(2): 270-274. 